\title{
A Comparative Study on Lipid and Protein Composition of Oreochromis niloticus Muscles from Five Different Localities in Egypt
}

\author{
Salwa K. El- Nabarawy \\ Zoology department, Faculty of Science, Al Azhar University (Girls Branch), \\ Nasr City, Cairo.
}

\begin{abstract}
This study was aimed to compare the muscle lipid and protein composition of Oreochromis niloticus from five different localities in Egypt in order to determine the most nutritionally valuable samples based on the mode of feeding supplied. The fish samples were brought from the River Nile (natural feeding), Ismailia Canal (zooplankton feeding) and three fish aquacultures; Balteem (low protein diet, 18\%), Al Abbasa (high protein diet, 30\%) and Al Qanater Al Khaireya (zooplankton feeding in concrete tanks). Muscle total protein and total lipid contents were estimated. Fatty acid and amino acid analysis were carried out. Studying muscle protein fractions was undertaken using SDS-PAGE electrophoresis.

Results showed that the highest total proteins content was detected in the River Nile sample, while the lowest was estimated in Al Qanater fish sample. The percentage value of essential amino acids in the fish muscles from Al Abbasa was higher $(45.6 \%)$ than the other four localities. Total lipids were found to have the highest value in Al Abbasa aquaculture sample whereas the lowest level was detected in the River Nile sample. Analysis of fatty acids and amino acids revealed variable differences between all the examined samples from the five localities. Polyunsaturated fatty acid (PUFA) analysis showed that omega-3 had the highest \% value in O. niloticus from the River Nile and Al Abbasa localities (30.30 and 30.36 respectively), while omega-6 fatty acids were higher in the fish samples from Balteem and Al Qanater (35.5\% and 36.08\% respectively) than the other fish samples. Elecrtophoretic data analysis showed that the highest number and percentage values of protein fractions among the five localities were recorded in sample obtained from the River Nile.

It could be concluded that the best nutritional fish muscle quality was related to natural feeding in the River Nile sample and that fed on high protein diet at $\mathrm{Al}$ Abbasa aquaculture.
\end{abstract}

Keywords: Oreochromis niloticus, fatty acids, Amino acids, Electrophoresis, Omega fatty acids, Essential amino acids.

\section{INTRODUCTION}

Tilapias are very important in world fisheries, and are the second most important group of food fishes in the world. Nile tilapia, Oreochromis niloticus accounted for a harvest of nearly 2.54 million tones in 2009 (FAO, 2011). Although, native to Africa, tilapias are cultured in Asia and the Far East and the Southern United States (Maclean et al., 2002).Flesh quality has gained importance among consumers and in the aquaculture industry because it is directly related to human health and nutrition. In order to meet the increase in human fish demand, aquaculture is increasing along the necessity of supplying fish products of high quality and also diversified product (Queméner et al., 2002). Generally, an important success factor is that consumers accept farmed fish to be equivalent or superior to the wild fish 
(Olsson et al., 2003). Quality terms and how they are perceived differ for the fish farmer, processing industry and consumer.

Fish is highly nutritious, tasty and easily digested. Fish contains significant amounts of all essential amino acids, particularly lysine in which cereals are relatively poor. Fish protein can be used therefore to complement the amino acid pattern and improve the overall protein quality of a mixed diet (FAO, 2005).

In human nutrition, fatty acids such as linoleic and linolenic acids - important for preventing skin diseases - are considered essential as they cannot be synthesized by the organism. However, fish oils contain other "essential" polyunsaturated fatty acids which act in the same way as linoleic and arachidonic acids. As members of the linolenic acid family (first double bond in the third position, omega-3, counted from the terminal methyl group), they also have neurological benefits in growing children. Convincing evidence now exists for the significant role fish and fish oils play in decreasing the risk of developing cardiovascular diseases and in improving foetal brain development (Elvevoll and James, 2002). Fish lipids are well known to be rich in long-chain (LC) n-3 polyunsaturated fatty acids (LC n-3 PUFA), especially eicosapentaenoic acid (EPA) and docosahexaenoic acid (DHA). Long chain, n-3 PUFA cannot be synthesized by humans and must be obtained from the diet (Alasalvar et al.,2002). The importance of fish as a source of polyunsaturated fatty acids (PUFA), particularly n-3 fatty acids in human nutrition is widely recognized (Simopoulos, 2004). These fatty acids (3PUFA) have been associated to numberless benefits to human health. In general, they contribute to the prevention of heart diseases (Lee and Lip, 2003; Leigh-Firbank et al., 2002; Krisetherton et al., 2002.

Thus, this study was carried out to determine the proximate, fatty acid and amino acid composition of the common freshwater fish species Oreochromis niloticus in order to evaluate and compare the flesh quality (muscles lipid and protein chemical composition) of wild and cultured Nile tilapia, O. niloticus collected from River Nile, Ismailia Canal and cultured in Balteem, Al Abbasa and Al- Qanater Al Khairya aquacultures.

\section{MATERIAL AND METHODS}

\section{Fish samples}

Fish samples of Nile tilapia, Oreochromis niloticus were obtained from the River Nile (Cairo Governorate), Ismailia Canal (Ismailia Governorate), Balteem (Kafr Elsheikh Governorate), Al Abbasa (Sharqia Governorate) and Al Qanater Al Khairya (Qalyobia Governorate) aquacultures. Three samples from each locality with equal number of fish were chosen randomly for muscle chemical analysis.

\section{Preparation of fish muscle samples for biochemical analysis}

A fixed weight $(1.0 \mathrm{~g})$ of the fish dorsal muscle was homogenized in a glass homogenizer for 3 minutes in $5 \mathrm{ml}$ saline, then it centrifuged at 3000 r.p.m for 10 minutes. The supernatant was used for determination of total protein and total lipid contents.

\section{Biochemical analysis}

Total protein and total lipid contents were determined using commercial colorimetric kits (Diamond Diagnostic, Egypt), according to the methods of Gornal et al. (1949) and Zollner and Kirsch (1962) respectively. Fatty acids were analyzed and characterized by the method of Ackman (1991). Amino acids analysis was performed according to the method described by Gam et al. (2005). 


\section{SDS-polyacrylamide gel electrophoresis}

Protein patterns were running gel according to the method of Laemmli (1970).

\section{Statistical analysis}

Values were expressed as means \pm standard deviation $(\mathrm{M} \pm \mathrm{SD})$. Data were analyzed using t-test (Snedecor, 1962).

\section{RESULTS}

\section{Total lipid content}

The mean total lipid content of O. niloticus ranged from 0.64 to $0.96 \mathrm{mg} / 100 \mathrm{~g}$ tissue as shown in Fig. (1). The highest lipid content was obtained on the samples from Al Abbasa, Balteem and Al Qanater aquacultures (0.96, 0.94 and $0.89 \mathrm{mg} / 100 \mathrm{~g}$ wet weight respectively), while the lowest was in samples of the River Nile and Ismailia Canal as presented in Fig. (1).

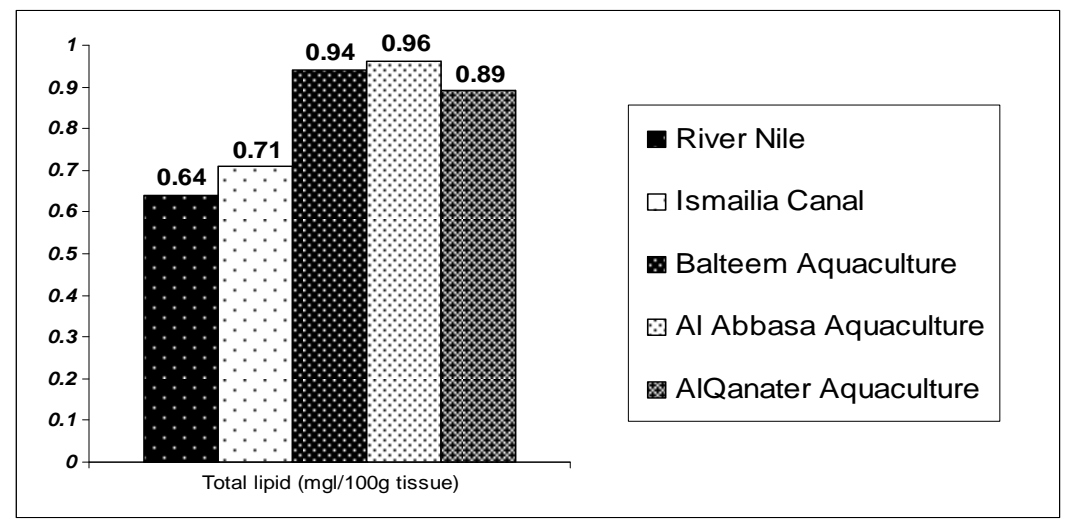

Fig. 1: Total lipid (mg/100g) wet weight of O. niloticus muscles from five different localities

\section{Fatty acid content}

The fatty acid composition ( $\mathrm{mg} / \mathrm{g}$ tissue) of the freshwater O. niloticus is summarized in Table (1). The sequence of the fatty acids is ordered according to their chromatographic retention times.

The fatty acid composition of the studied fish muscles from the five different localities ranged from 27.38 to $32.63 \mathrm{mg} / \mathrm{g}$ tissue (in Ismailia canal and the River Nile samples respectively). Omega-3 fatty acid levels in the fish muscles were relatively high in the River Nile and Al Abbasa samples (30.30\% and 30.36\% respectively) compared to the other groups. Omega- 6 also among them those occurring in the highest proportions were Balteem (35.50\%) and Al Qanater (36.08\%) aquacultures as shown in Table (2). 
Table 1: Fatty Acid composition (mg/g tissue) of $O$. niloticus muscles from five different localities in Egypt.

\begin{tabular}{|c|c|c|c|c|c|}
\hline \multirow[b]{2}{*}{ Fatty acid } & \multicolumn{5}{|c|}{ Fish localities } \\
\hline & River Nile & Ismailia Canal & $\begin{array}{c}\text { Balteem } \\
\text { Aquaculture }\end{array}$ & $\begin{array}{c}\text { Al Abbasa } \\
\text { Aquaculture }\end{array}$ & $\begin{array}{l}\text { Al Qanater } \\
\text { Aquaculture }\end{array}$ \\
\hline Myristic acid & 0.521 & 0.650 & 0.578 & 0.669 & 0.551 \\
\hline C15:0 Pentadecanoic acid & 0.290 & 0.235 & 0.209 & 0.318 & 0.307 \\
\hline Palmitic acid & 3.452 & 3.527 & 4.077 & 3.628 & 2.658 \\
\hline C16:1n-7 Palmitoleic acid & 2.459 & 1.991 & 1.770 & 2.048 & 2.601 \\
\hline C17:0 Heptadecanoic acid & 1.026 & 0.831 & 0.738 & 0.845 & 0.790 \\
\hline C18:0 Stearic acid & 1.368 & 1.108 & 0.985 & 1.139 & 1.447 \\
\hline C18:1n-9 Oleic acid & 1.628 & 1.318 & 1.172 & 1.356 & 1.722 \\
\hline C18:'n-7 Vaccenic acid & 0.959 & 1.197 & 1.384 & 1.232 & 1.015 \\
\hline C18:2n-6 Linoleic acid & 1.511 & 1.590 & 1.837 & 1.324 & 1.843 \\
\hline C18:3 n-6 Linolenic acid & 0.438 & 0.461 & 0.410 & 0.384 & 0.464 \\
\hline C18:3n-3 Linolenic acid & 0.595 & 0.626 & 0.724 & 0.691 & 0.458 \\
\hline C20:0 Arachidic acid & ND & ND & ND & ND & ND \\
\hline Gadoleic acid & ND & ND & ND & ND & ND \\
\hline C20: 2n-6 Eicosadienoic acid $\quad$ (omega6) & 0.142 & 0.219 & 0.253 & 0.208 & 0.150 \\
\hline C20 :3n-6 Eicosatrienoic acid & 0.554 & 0.408 & 0.363 & 0.555 & 0.586 \\
\hline C20:4n-6 Arachidonic acid & 1.437 & 1.512 & 1.748 & 1.442 & 1.521 \\
\hline C20 :3n-3 Eicosatrienoic acid & ND & ND & ND & ND & ND \\
\hline C20 :4n-3 Eicsoatetraenoic acid (omega3) & 0.758 & 0.510 & 0.590 & 0.694 & 0.583 \\
\hline C20 :5n-3 Eicosapentaenoic acid (omega3) & 1.763 & 1.187 & 1.055 & 1.615 & 1.357 \\
\hline C22: $0 \quad$ Behenic acid & 0.238 & 0.257 & 0.348 & 0.403 & 0.290 \\
\hline C22: 4n-6 Docosatetraenoic acid (omega6) & 1.059 & 1.014 & 0.901 & 0.706 & 1.121 \\
\hline C22 :5n-6 Clupanodonic acid & 5.656 & 3.808 & 4.403 & 5.181 & 5.984 \\
\hline C22 :5n-3 Clupanodonic acid & 5.850 & 3.939 & 3.502 & 5.359 & 6.189 \\
\hline C22:6n-3 Docosahexaenoic acid (omega3) & 0.921 & 0.995 & 0.884 & 0.985 & 0.709 \\
\hline Total & 32.63 & 27.38 & 27.93 & 30.78 & 32.35 \\
\hline
\end{tabular}

Table 2: Omega fatty Acid percentage values of O. niloticus muscles from five different localities in Egypt.

\begin{tabular}{|c|c|c|c|c|c|}
\hline \multirow{2}{*}{ Omega fatty acids } & \multicolumn{5}{|c|}{ Percentage values } \\
\cline { 2 - 6 } & River Nile & $\begin{array}{c}\text { Ismailia } \\
\text { Canal }\end{array}$ & $\begin{array}{c}\text { Balteem } \\
\text { Aquaculture }\end{array}$ & $\begin{array}{c}\text { Al Abbasa } \\
\text { Aquaculture }\end{array}$ & $\begin{array}{c}\text { Al Qanater } \\
\text { Aquaculture }\end{array}$ \\
\hline Omega 3 & 30.30 & 26.50 & 24.18 & 30.36 & 28.74 \\
\hline Omega 6 & 33.09 & 32.91 & 35.50 & 31.84 & 36.08 \\
\hline
\end{tabular}

\section{Total protein content}

The total protein content of $O$. niloticus ranged from 12.26 to $16.77 \mathrm{~g} / 100 \mathrm{~g}$ wet weight (Fig., 2). No significant difference was noted $(\mathrm{p}>0.05)$ between the five fish samples. The highest protein content was recorded on the River Nile fish muscles.

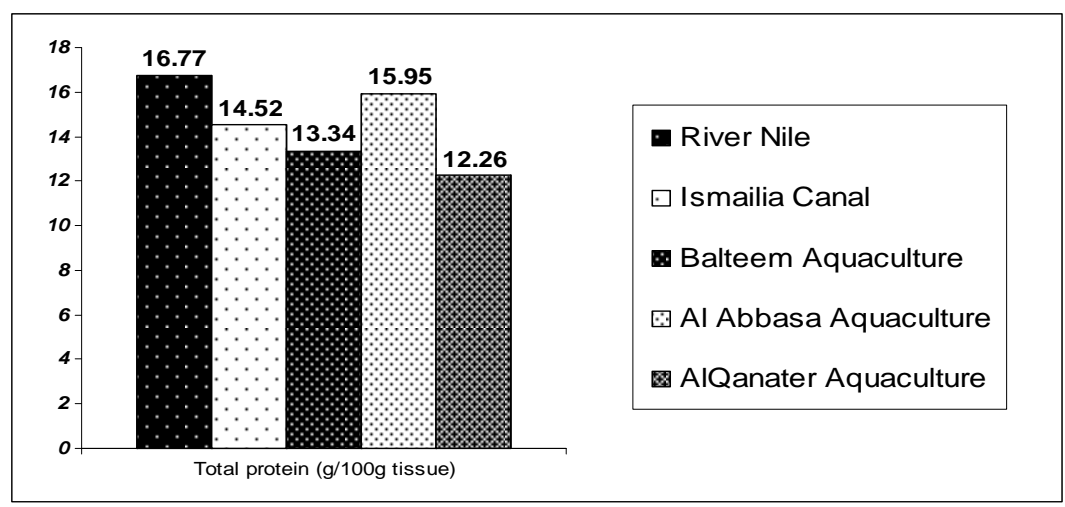

Fig. 2: Total protein $(\mathrm{g} / 100 \mathrm{~g})$ wet weight of $O$. niloticus muscles from five different localities.

\section{Amino acid content}

Seventeen different amino acids were obtained in the freshwater fish $O$. niloticus. The total amino acid content was presented in Table (2) as $\mu \mathrm{mol} / \mathrm{g}$ protein. 
Eight of the nine essential amino acids that are very important for the human body are separated in this fish species. These essential amino acids are histidine, isoleucine, leucine, lysine, methionine, phenylalanine, threonine and valine. Tryptophan could not be detected by this technique. Total amino acid concentration had the highest level in the River Nile sample $(91.646 \mu \mathrm{mol} / \mathrm{g}$ protein $)$, while the essential amino acid percentage value was $43.99 \%$ (Table 3 ). The major essential amino acids values $(45.60 \%)$ was recorded in the fish muscles obtained from Al Abbasa aquaculture compared to the other samples while the total amino acid content of this sample was $79.487 \mu \mathrm{mol} / \mathrm{g}$ protein (Table, 3 ).

Table 3: Amino Acid composition (umol/g protein) of O. niloticus muscles from five different localities in Egypt

\begin{tabular}{|l|c|c|c|c|c|}
\hline \multirow{2}{*}{ Amino acid } & \multicolumn{5}{c|}{ Fish localities } \\
\cline { 2 - 6 } & $\begin{array}{c}\text { River } \\
\text { Nile }\end{array}$ & $\begin{array}{c}\text { Ismailia } \\
\text { Canal }\end{array}$ & $\begin{array}{c}\text { Balteem } \\
\text { Aquaculture }\end{array}$ & $\begin{array}{c}\text { Al Abbasa } \\
\text { Aquaculture }\end{array}$ & $\begin{array}{c}\text { Al Qanater } \\
\text { Aquaculture }\end{array}$ \\
\hline Alanine & 3.612 & 4.009 & 4.450 & 4.495 & 4.541 \\
\hline Arginine & 8.339 & 7.338 & 6.458 & 5.001 & 3.873 \\
\hline Aspartic acid & 8.229 & 8.640 & 7.604 & 5.888 & 4.560 \\
\hline Glutamic acid & 13.422 & 12.205 & 12.751 & 12.113 & 14.778 \\
\hline Glycine & 4.221 & 4.007 & 4.010 & 3.809 & 3.619 \\
\hline Histidine* & 2.841 & 2.010 & 2.699 & 2.564 & 2.436 \\
\hline Isoleucine* & 2.294 & 2.108 & 2.179 & 2.070 & 1.967 \\
\hline Leucine* & 8.055 & 8.221 & 7.286 & 8.088 & 7.316 \\
\hline Lysine* & 8.611 & 7.022 & 8.180 & 7.771 & 7.383 \\
\hline Methionine* & 3.147 & 3.328 & 2.868 & 2.615 & 2.383 \\
\hline Phenylalanine* & 5.044 & 5.116 & 4.598 & 4.191 & 3.820 \\
\hline Proline & 3.416 & 3.113 & 3.245 & 3.082 & 2.928 \\
\hline Serine & 5.055 & 5.282 & 4.608 & 4.200 & 3.828 \\
\hline Threonine* & 5.216 & 5.112 & 4.955 & 4.707 & 4.472 \\
\hline Tyrosine & 4.221 & 4.015 & 4.010 & 3.809 & 3.619 \\
\hline Valine* & 5.108 & 5.213 & 4.656 & 4.244 & 3.868 \\
\hline Cystine & 0.815 & 0.756 & 0.806 & 0.840 & 0.805 \\
\hline Tryptophan & $\mathrm{ND}$ & $\mathrm{ND}$ & $\mathrm{ND}$ & $\mathrm{ND}$ & $\mathrm{ND}$ \\
\hline Total amino acids content & 91.646 & 87.495 & 85.363 & 79.487 & 76.196 \\
\hline \% value of Essential amino acids & 43.99 & 43.58 & 43.84 & 45.60 & 44.16 \\
\hline ND
\end{tabular}

ND : Not detected *: Essential Amino acid

\section{SDS-polyacrylamide gel electrophoresis}

Protein patterns determined by SDS-polyacrylamide gel electrophoresis revealed 21 protein bands in the muscle tissue of the River Nile sample and Al Abbasa (19 band), which is the highest band number among the tested samples from the different localities; while the least band number (14) was in Balteem sample. The band numbers and percentages of all samples are summarized in Table (4). Fig. (3) shows the electrophoregram and densitometric profile of protein fractions of the studied fish muscles of $O$. niloticus. Analysis of electrophoretic data in Fig. (3) revealed variable changes specially in the high (bands 1-5) and low (bands $15-21$ ) molecular weight regions in all the four localities compared to the that of the River Nile. It was also noticed that bands 17- 21 disappeared in Ismailia Canal and Balteem and Al Qanater fish muscle samples. 
Table 4: Number and percentages of O. niloticus muscle protein fractions separated by SDS-PAGE from different localities.

\begin{tabular}{|c|c|c|c|c|c|}
\hline \multirow{2}{*}{$\begin{array}{c}\text { Band } \\
\text { number }\end{array}$} & \multicolumn{5}{|c|}{ Band \% of muscle protein fractions } \\
\cline { 2 - 6 } & River Nile & $\begin{array}{c}\text { Ismailia } \\
\text { Canal }\end{array}$ & $\begin{array}{c}\text { Balteem } \\
\text { Aquaculture }\end{array}$ & $\begin{array}{c}\text { Al Abbasa } \\
\text { Aquaculture }\end{array}$ & $\begin{array}{c}\text { Al Qanater } \\
\text { Aquaculture }\end{array}$ \\
\hline 1 & 5.72 & 8.49 & 6.30 & 3.07 & 5.57 \\
\hline 2 & 1.77 & 5.25 & 5.36 & 2.30 & 3.10 \\
\hline 3 & 3.17 & 6.35 & 9.67 & 3.21 & 10.52 \\
\hline 4 & 2.31 & 16.32 & 15.69 & 3.67 & 10.82 \\
\hline 5 & 3.45 & 5.00 & 8.39 & 7.76 & 12.14 \\
\hline 6 & 5.26 & 1.55 & 3.71 & 14.88 & 1.64 \\
\hline 7 & 1.03 & 3.51 & 0.75 & 7.40 & 4.51 \\
\hline 8 & 2.43 & 3.15 & 5.47 & 2.26 & 2.82 \\
\hline 9 & 14.79 & 3.95 & 1.43 & 3.60 & 1.61 \\
\hline 10 & 2.86 & 1.94 & 1.84 & 1.70 & 2.17 \\
\hline 11 & 0.96 & 1.74 & 19.39 & 1.17 & 3.43 \\
\hline 12 & 1.19 & 19.38 & 2.69 & 1.78 & 1.97 \\
\hline 13 & 4.15 & 7.50 & 6.73 & 2.24 & 20.77 \\
\hline 14 & 4.35 & 5.61 & 12.58 & 2.25 & 5.56 \\
\hline 15 & 1.94 & 10.27 & - & 1.64 & 4.54 \\
\hline 16 & 1.19 & - & - & 19.34 & 8.82 \\
\hline 17 & 4.27 & - & & 6.20 & \\
\hline 18 & 11.65 & - & - & 5.20 & - \\
\hline 19 & 14.58 & - & - & 10.35 & - \\
\hline 20 & 4.27 & - & - & - & - \\
\hline 21 & 8.68 & - & - & & - \\
\hline
\end{tabular}

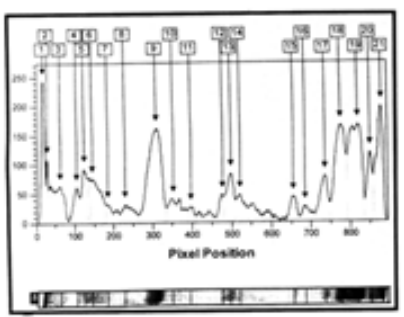

A

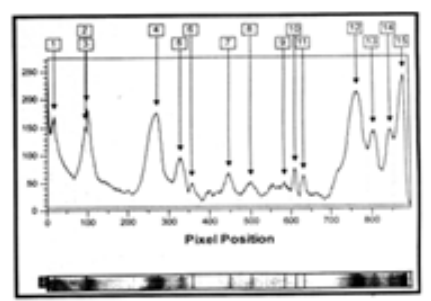

B

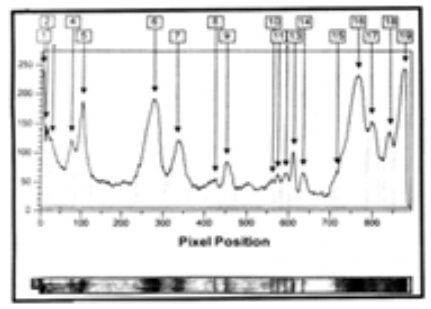

D

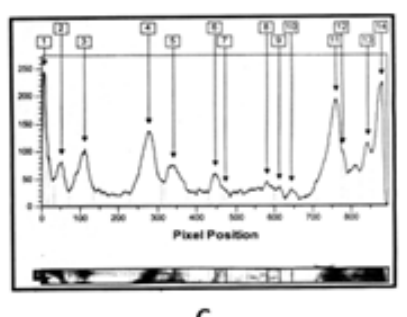

C

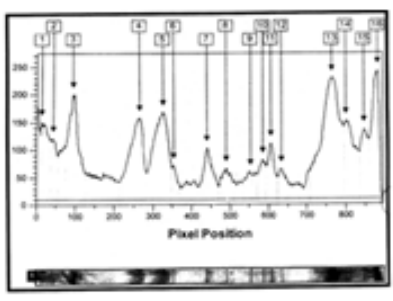

E

Fig. 3 : Elecrtophoregram and densitometric profile of O. niloticus muscle proteins separated by SDS-PAGE. 


\section{DISCUSSION}

Fish is a vital component of food in most developing countries especially in Egypt. The production and consumption of freshwater fish, has increased during recent years. Therefore effort is needed to improve the output performances and quality of the freshwater fish. Oreochromis niloticus, commonly known as the Nile tilapia, is a popular food fish that has been farmed in ponds for thousands of years. Lipids are an important component in human diets, both as energy and fatty acids (FA) sources (Sargent et al., 1989). Fish, like other animals, have the ability to accumulate lipids in their body. Fat content is influenced by species, geographical region, age, and diet (Tacon, 1990).

The physiological status of farmed fish is an integral part for evaluating their health status. However, physiological alterations might be used as indicators for unsuitable environmental conditions (Cnaani et al. 2004 and Řehulka et al. 2004).

The present results showed that the total lipid content was highest in fish muscle from Al Abbasa compared to the River Nile sample which had the lower muscle total lipid content. Serum lipids increased significantly due to the increase in protein level, and it may be because the muscle is a pivotal compartment directly linked to amino acid turnover. This involves protein synthesis or breakdown of those molecules as energetic substrates (Gallagher, 1999). It is generally recognized that PUFA composition may vary among species of fish but little attention has been paid to the PUFA composition of different species when selecting fish for diets. All fish were considered of similar nutritional value and selection was made primarily on the basis of availability, freshness, flavour and similar factors (Turker et al. 2003). Among the fatty acids, particular emphasis has been placed on the omega-3 and omega-6 polyunsaturated fatty acids (PUFA). Polyunsaturated omega-3 fatty acid, eicosapentaenoic acid (EPA, C-20:5) and docosahexaenoic acid (DHA, C-22:6), are of interest because they reduce the risk of cardiovascular diseases (Leaf and Weber, 1988and Kang and Leaf, 1996). Since these fatty acids composition may vary among fish species, it is necessary to determine both the lipid content and the PUFA distribution. This importance in fatty acid profile of fish stems from their importance in human health, mainly in reducing the occurrence of heart diseases, strokes and various inflammatory injuries, and improving neurological function in newborn infants (Kefatos et al 1997 and Maina et al. 2003). In that area, findings have confirmed that body fatty acid profile to a large extent mirrors the dietary fatty acid composition (Maina et al. 2003 and Williams et al.2003). Hence, differences could appear between tank and pond rearing systems, due to the natural food present in the latter, when feeding fish with same artificial diets.

Biochemical analysis of the fish muscle of Oreochromis niloticus in the present study showed no significant change in the protein content among the five studied samples. These results confirm the results obtained by El -Kasheif et al (2011) who found no significant change in the serum total protein in response to change of fish diet in O. niloticus. On the other hand, Kheir (1997) found that total protein content increased with increasing supplemented oil and the highest protein content in muscles of Oreochromis aureus was recorded with 6\% lipid. Also, Serum and muscle proteins tended to increase with increased dietary protein level in Nile tilapia (Abdel-Tawwab et al. 2010 and Abdelhamid et al., 2014).

Amino acids are also important in healing processes and the composition of amino acids in fish is similar to that in man, people can acquire essential amino acids in abundance and proper balance by eating fish. The essential amino acids cannot be 
manufactured in human bodies, but can be obtained from food. The present study indicated that the samples of fresh water $O$. niloticus muscles obtained from the five studied localities had all the essential amino acids. Deficiency in the essential amino acids may hinder healing recovery process (Zenebe et al. 1998). Leucine promotes the healing of bones, skin and muscle tissue. Isoleucine is necessary for hemoglobin formation, stabilizing and regulating blood sugar and energy. Glycine, which is one of the major components of human skin collagen, together with other essential amino acids such as alanine form a polypeptide that will promote re-growth and tissue healing (Kang'ombe et al., 2006). Other reports of similar nature provided valuable information on selecting fish and fish oils for nutritional purposes (Saha and Dewan, 1979 and Bahurmiz and $\mathrm{Ng}, 2007)$.

Electrophoresis is an analytical method in which substances are separated from one another based upon their differing rates of migration in a strong electric field. Muscle protein consists mainly of actin and myosin, but numerous other proteins also make up muscle tissue. Variations in an organism's proteins may reflect physiological adaptations to an ecological niche and environment. Polyacrylamide SDS gel electrophoresis was used in the present study to separate muscle protein fractions. Numerous studies had special concern in analyzing the fish muscle proteins electrophoretically. In Nile Tilapia O. niloticus (Tongnuanchan et al., 2011 and Monter-rey-Quintero and Sobral, 2000). Also, Ferreira et al., (2013) studied the muscle proteins of the White mouth Croaker, Micropogonias furnieri. Furthermore, the present results showed that muscle proteins of O. niloticus separated by SDSPAGE revealed that the River Nile fish muscle was separated to 21 electrophoretic bands that was the largest number compared to the other fish samples, while the least band number (14) was in Balteem sample. Protein fractions were characterized to high, medium and low- molecular band proteins. Variable changes were also recorded between the different fish samples.

\section{CONCLUSION}

The present study indicated some differences and similarities in the biochemical composition of the muscles of Oreochromi niloticus obtained from five different localities belonging to five Governorates in Egypt. Fish samples were collected from the River Nile (Cairo G.), Ismailia Canal (Ismailia G.), Balteem (kafr El-Sheikh G.), Al-Abbasa (Al Sharqya G.) and Al-Qanater Al-Khairya (Al-Qalubyia G.) Fish muscle lipid and protein contents were estimated to evaluate the change in the fish muscle composition according to the mode of feeding available. Fish from the River Nile had natural feeding. Ismailia Canal fish samples were fed with zooplanktons. Balteem aquaculture provided low-proten diet (18\%), Al-Abbasa aquaculture provided relatively high protein Diet $(30 \%)$ and in Al-Qanater Al-Khairya aquaculture, fish were reared in concrete tanks and fed zooplanktons. The biochemical variations of the fish samples were to determine the nutritional value of each sample. The current results, based on the biochemical analysis performed, indicated that the fish samples obtained from natural habitat had better flesh qualities than that collected from aquacultures.

\section{REFERENCES}

Abdelhamid1, A.M.; A.I.Mehrim1, M.E.A. Seden2 and O.A. Zenhom (2014). Effect of different sources and levels of some dietary biological additives on: III- body 
composition and muscular histometric characteristics of Nile tilapia fish. Egypt. J. Aquat. Biol. \& Fish., 18 (1): 13-24.

Abdel-Tawwab, M.; Ahmad, M.H.; Khattab, Y.A.E. and Shalaby, A.M.E. (2010). Effect of dietary protein level, initial body weight, and their interaction on the growth, feed utilization, and physiological alterations of Nile tilapia, Oreochromis niloticus (L.). Aquacult., 298:267-274.

Ackman, R.G. (1991). Application 0f gas-liquid chromatography to lipid separation and analysis. In Analysis of Fats, Oils and Lipoproteins. (E.G. Perkins, ed.) pp.270-300. American Oil Chemists' Society.

Alasalvar, C.; Taylor, K.D.; Zubcov, E.; Shahidi, F. and Alexis, M. (2002). Differentiation of cultured and wild sea bass (Dicentrarchus labrax): Total lipid content, fatty acid and trace mineral composition. Food Chemistry,79: 145-150.

Cnaani, A.; Tinman, S.; Avidar Y.; Ron, M. and Hulata, G. (2004). Comparative study of biochemical parameters in response to stress in Oreochromis aureus. O. mossambicus and two strains of O. niloticus. Aquacult Res., 35:1434-1440.

El -Kasheif, M. A. ; Saad, A. S. and Seham, A. I. (2011). Effects of varying levels of fish oil on growth performance, body composition and haematological characteristics of Nile tilapia Oreochromis niloticus (L). Egypt J. Aquat. Biol. \& Fish., 15(1): $125-141$.

Elvevoll, E. and James, D. (2002).Fish oils in foetal and neonatal development. FAO/WHO Joint expert consultation on diet, nutrition and the prevention of chronic disease. Geneva, 28 January - 1 February. 53.

FAO (2011). The State of World Fisheries and Aquaculture, Food and Agriculture Organization, Rome, Italy.

FAO(2005).United Nations Food \& Agriculture Organization, Nutritional elements of fish. FAO, Rome.

Ferreira, F.de Andrade; Freire B. P.; Andreghetto de Souza, J. T.; Cortez-Vega, W. R. and Prentice, C. (2013). Evaluation of Physicochemical and Functional Properties of Protein Recovered Obtaining from White mouth Croaker (Micropogonias furnieri) Byproducts. Food and Nut. Sci., 4: 580-585.

Gallagher, M.L. (1999). Growth response, tissue composition, and liver enzymes changes in juvenile sunshine bass Morone chrysops xM. saxatilis, associated with dietary protein and lipid level. J. Appl. Aquacult., 9:41-51.

Gam, Lay-Harn; Leow, chiuan-Yee and Baie,S. (2005). Amino Acid Composition of Snakehead Fish (Channa striatus) of Various Sizes Obtained at Different Times of the Year. Malaysian Journal of Pharmaceutical Sciences, 3(2): 19-30.

Gornall, A.G. ; Bardawill, G.J. ; and Parid M.M. (1949). Method of determination protein in serum blood. $J$ Biol Chem., 177: p. 751

Kang, J. X. and A. Leaf. (1996). The cardiac antiarrhytmic effects of polyunsaturated fatty acid. Lipids, 31: 41-44.

Kang'ombe, J.; Brown, J.A. and Halfyard, L.C. (2006). Effect of using different types of organic animal manure on plankton abundance, and on growth and survival of Tilapia rendalli (Boulenger) in ponds. Aquacult. Rese., 37: 1360-1371.

Kefatos, A.; Diacatou, A.; Voukiklaris, G.; Nikolakakis, N.; Vlachonikolis, J.; Kounali, D.; Mamalakis, G. and Dontas, A.S. (1997). Heart disease risk factor status and dietary changes in the Cretan population over the past 30 years: The Seven country study. Am. J. Clin. Nut., 65:1882-1886.

Kheir, M.T. (1997). Growth of caged Oreochromis auraus (Steindachner, 1864) 
Kris-Etherton, P. M.; HarriIs, W. S.; Appel, L. J. (2002). Fish consumption, fish oil, omega-3 fatty acid, and cardiovascular disease. Circulation, 106 (21): 2747-2757.

Laemmli, U.K. (1970). Cleavage of structural proteins during the assembly of the head of bacteriophage T4. Nat., 227:680-685.

Leaf, A. C. and Weber P. C. (1988). Medical progress. Cardiovascular effects of n-3 fatty acids. New England J. Med., 318: 549-557.

LEE, K. W.; LIP, G. Y. H. (2003). The role of omega-3 fatty acid in the secondary prevention of cardiovascular disease. Quar. J.Med., 96 (3):465-480.

Leigh-Firbank, E. C.; Minihane, A. M.; Leake, D. S.; Wright, J. W.; MurphyY, M. C.; Griffin, B. A. and Williams, C. M. (2002). Eicosapentaenoic acid and docosahexaenoic acid from fish oils: differential associations with lipid responses. British J. Nut., 87(5): 435-445.

Maclean, N.; Rahman, M.A.; Sohm, F.; Hwang, G.; Iyengar, A.; Ayad, H.; Smith,A. and Farahmand, H. (2002). Transgenic tilapia and the tilapia genome. Gene, 295: 265-277.

Maina, J. G.; Beames, R. M.; Mbugua, P. N.; Iwama, G. and Kisia, S. M. (2003). Partial replacement of fishmeal with sunflower cake and corn oil in diets for tilapia Oreochromis niloticus (Linn): Effect on whole body fatty acids. Aquacult.Res., 34: 595-608.

Monterrey-Quintero E. S. and Sobral, P. J. A. (2000). "Preparo e Caracterização de Proteínas Miofibrilares de Tilápia-do- Nilo Para Elaboração de Biofilmes," Pesquisa Agrope- cuária Brasileira, 35(1): 179-189.

Olsson, G.B.; Olsen, R.L.; Carlehög, M. and Ofestad, R. (2003). Seasonal variations in chemical and sensory characteristics of farmed and wild Atlantic halibut (Hippoglossus hippoglossus). Aquacult., 217: 191- 205.

Queméner, L.; Suquet, M.; Mero, D. and Gaignon, J. L. (2002). Selection method raised on artificial feeds with different levels of lipids. Egypt. J. Z001., 28: 77- 86.

Řehulka, J.; Minařík, B. and Řehulková, E. (2004). Red blood cell indices of rainbow trout Oncorhynchus mykiss (Walbaum) in aquaculture. Aquacult Res., 35: $529-546$.

Sargent, J.R. (1997). Fish oils and human diet. British Journal of Nutrition, 78 (Suppl. 1): 5-13.

Silmopoulos, A. P. (2004). Omega-6/omega-3 essential fatty acid ratio and chronic diseases. Food Reviews International, 20(1): 77-90.

Snedecor, G.W.(1962). Statistical Methods 5th ed. The Iowa University Press Ames. Iowa, USA.

Tacon, A.G.J. (1990). Standard methods for the nutrition and feeding of farmed fish and shrimp. Argent Laboratories Press, Washington DC. of new candidates for finfish aquaculture: the case of the French Atlantic, the channel and the North Sea coasts. Aquat. Living Resour., 15: 293-302.

Tongnuanchan, P.; Benjakul S. and Prodpran T. (2011) "Roles of Lipid Oxidation and $\mathrm{pH}$ on Properties and Yellow Dis- colouration during Storage of film from Red Tilapia (Oreochromis niloticus) Muscle Protein," Food Hydrocolloids, 25 3: 426-433.

Turker, H.; Eversole, A. and Brune, D.E. (2003). Effect of temperature and phytoplankton concentration on Nile tilapia Oreochromis niloticus (L.) filtration rate. Aquacul- ture Research, 34: 453-459. 
Williams, K.C., Paterson, B.D., Barlow, C.G., Ford, A. and Roberts, R. (2003). Potential of meat meal to replace fish meal in extruded dry diets for Barramundi, Lates calcarifer (Bloch). II. Organoleptic characteristics and fatty acid composition. Aquacult. Rese., 34: 33-42.

Zenebe, T.; Ahlgren G., Gustafsson I. B., and Boberg, M. (1998). Fatty acid and lipid content of Oreochromis niloticus L. in Ethiopian lakes -dietary effects of phytoplankton. Ecology of Freshwater Fish, 7: 146-158.

Zollner, N. and Kirsch, K. (1962). "Colorimetric method for determination of total lipids”. Z. Ges. Exp. Med., 135: 545 -550.

\footnotetext{
ARABIC SUMMRY

دراسة مقارنة على محتوى الاهون والبروتينات في عضلات سمكة البلطي النيلي من مناطق مختلفة في مصر

سلوى كمال النبراوي

قسم علم الحيو ان، كلية العلوم، جامعة الأزهر (فرع البناوي)، مدينة نصر ، القاهرة

تهذف هذه الدراسة إلى مقارنة محتوى الدهون والبروتينات في سمكة البلطي النبلي أوريوكرومبيس

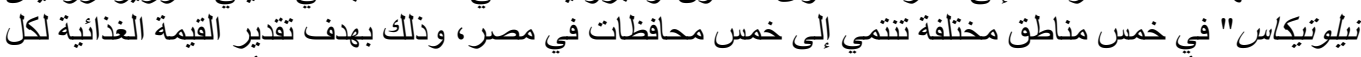

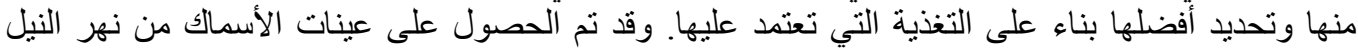

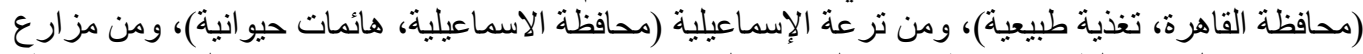

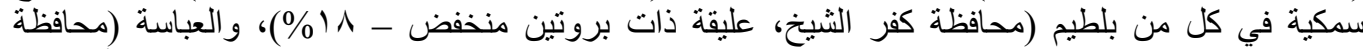

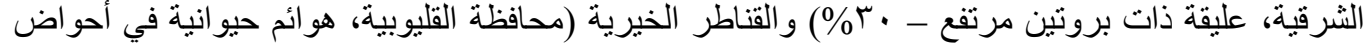

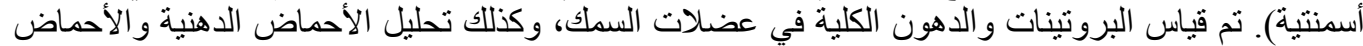

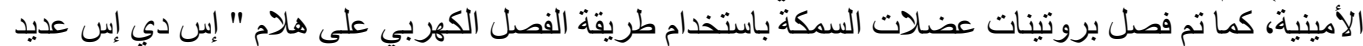

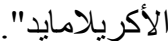

وقد أظهرت النتائج أن أعلى نسبة للبروتين الكلي كانت في عينات نهر النيل بينما كانت أقلها في عينة

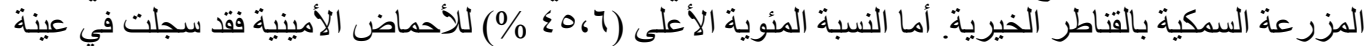

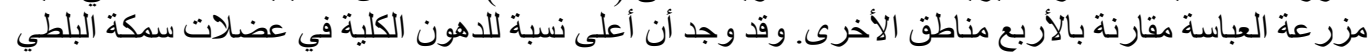

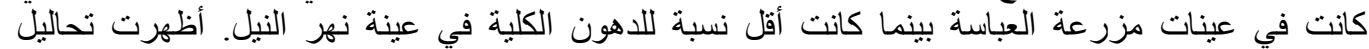

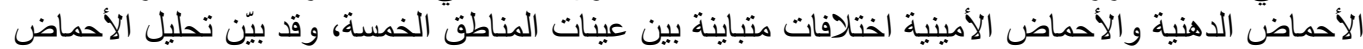

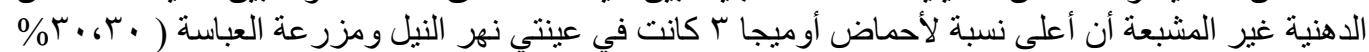

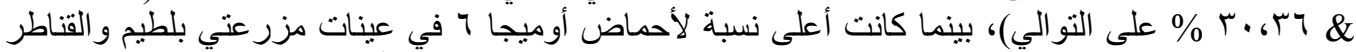

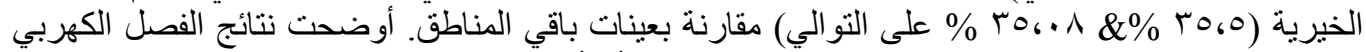

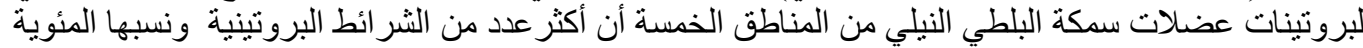

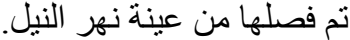
ويستخلص مما سبق أن القيمة الغذائية ونوعية عضلات النية السمكة ترتبط بنوعية الغذاء الطبيعي في عينة نهر النيل والتغذية على عليقة ذات بروتين عالي في مزرعة العباسة.
} 